University of Nebraska - Lincoln

DigitalCommons@University of Nebraska - Lincoln

Nebraska Game and Parks Commission -- Staff Research Publications

Nebraska Game and Parks Commission

August 1967

\title{
A Noteworthy Record of the Swift Fox in McPherson County, Nebraska
}

Lawrence J. Blus

Nebraska Game, Forestation and Parks Commission

Glenn R. Sherman

Nebraska Game, Forestation and Parks Commission

John Henderson

Nebraska Game, Forestation and Parks Commission

Follow this and additional works at: https://digitalcommons.unl.edu/nebgamestaff

Part of the Environmental Sciences Commons

Blus, Lawrence J.; Sherman, Glenn R.; and Henderson, John, "A Noteworthy Record of the Swift Fox in McPherson County, Nebraska" (1967). Nebraska Game and Parks Commission -- Staff Research Publications. 18.

https://digitalcommons.unl.edu/nebgamestaff/18

This Article is brought to you for free and open access by the Nebraska Game and Parks Commission at DigitalCommons@University of Nebraska - Lincoln. It has been accepted for inclusion in Nebraska Game and Parks Commission -- Staff Research Publications by an authorized administrator of DigitalCommons@University of Nebraska - Lincoln. 


\section{A NOTEWORTHY RECORD OF THE SWIFT FOX IN McPHERSON COUNTY, NEBRASKA}

An adult female swift fox (Vulpes velox) was killed by an automobile 1 mile E Ringgold, McPherson Co., Nebraska, on 25 March 1966. Standard external measurements (mm) of this specimen are: $723,275,132,59$, and weight, $2000 \mathrm{~g}$. This record is approximately 80 miles south of the nearest occurrence listed by Jones (Univ. Kansas Publ., Mus. Nat. Hist., 16: 1-356, 1964) and appears to be the first verification of the occurrence of this fox in the Nebraska Sandhills, although specimens have been taken on all sides of this area. Jones (1964) indicated that this species may have been extirpated in Nebraska in the early 1900 's as there was only one record of specimens being taken in the State (a female and two kits in 1953 or 1954) since 1900. Although this record of the swift fox raises more 
questions concerning possible changes in its range and numbers than are answered, it merits attention particularly since Jones (1964) indicated that this species is making an apparent comeback in the southern portion of its range.

The 20,000-sq-mile Sandhills area is comprised of a sandy prairie that is dominated by various postclimax grasses (Tolstead, Ecol. Monogr., 12: 255-292, 1942). The presence of this large block of potentially suitable habitat may favor an increase of this fox in the Sandhills and in other sparsely populated grasslands in western Nebraska. Also favoring a population increase in this species is the minimal amount of predator and rodent control in the Sandhills by the Division of Wildlife Services (U. S. Fish and Wildlife Service). A few prairie dog towns are poisoned each year, and approximately 200 poison bait stations are maintained in the Sandhills and vicinity by DWS (Ernest J. Giese, personal communication). Apparently, the control work of DWS offers little hazard to the swift fox, although control operations should be discontinued in local areas where swift foxes are known to occur as this species is extremely susceptible to poison baits, trapping, and other controls. DWS control work is conducted in less than half of the Sandhills; control operations are lacking in McPherson County. The number of swift foxes killed by the sparse human population in the Sandhills is thought to be minimal; however, some undoubtedly are mistakenly killed as young coyotes.

In order to prevent unnecessary killing of this species, the general public should be made aware of the plight and beneficial aspects of this fox (it appears to lack characteristics which are harmful to man) through increased coverage by newspapers and magazines. Laws protecting the swift fox should be considered in those states where it occurs.

We are grateful to George Jones who collected the specimen, to Dr. Harvey L. Gunderson of the University of Nebraska who verified our identification, and to C. Phillip Agee and Carl Wolfe who criticized the manuscript. The flat skin and skull are deposited in the University of Nebraska State Museum.-Lawrence J. Blus, GlenN R. ShrRman, and John D. Henderson, Nebraska Game, Forestation and Parks Commission, Thedford, Nebraska (present address of Blus: Patuxent Wildlife Research Center, Laurel, Maryland). Accepted 7 February 1967. 